\title{
Domestic and International Causes of Russian Military Intervention in Ukraine
}

\author{
Krajowe i międzynarodowe przyczyny rosyjskiej interwencji zbrojnej na Ukrainie
}

\section{- Abstract •}

The collapse of the Cold War order led to a change in the geopolitical environment of the Russian Federation. The declarations of independence of the former Soviet republics and the emergence of the post-Soviet area had weakened the country's position. As a result, the Russian Federation has been perceiving this new area as a zone of its 'vital interests', and attaining and maintaining dominant position in those territories has been considered crucial for the state's security, its strength and position on the international arena. Russia has been pursuing its goals in the area through numerous reintegration attempts on political, military and economic levels. To achieve the main political goal, which is the control over the post-Soviet area, the Russian Federation has been also using military instruments. The focal point and purpose of this article is to show the internal and external causes of military intervention of the Russian Federation in eastern Ukraine.

Keywords: post-Soviet area; Russian Federation; Ukraine; foreign policy; military conflicts; geopolitics

\section{- Abstrakt •}

Upadek pojałtańskiego porządku na świecie doprowadził do zmiany w geopolitycznym otoczeniu Federacji Rosyjskiej. Pozycja tego państwa uległa osłabieniu m.in. z uwagi na ogłoszenie niepodległości przez poszczególne republiki związkowe. Jednocześnie powstał tzw. obszar postradziecki. Dla Federacji Rosyjskiej wskazany obszar stanowi „strefę żywotnych interesów”, a zdobycie i utrzymanie dominującej pozycji ma zapewnić państwu bezpieczeństwo, wzrost siły i umocnienie pozycji na arenie międzynarodowej. Rosja realizuje swoje cele głównie przez próbę reintegracji obszaru postradzieckiego na płaszczyźnie politycznej, militarnej i gospodarczej. Do realizacji głównego celu politycznego, jakim jest kontrola nad obszarem postradzieckim, Federacja Rosyjska wykorzystuje elementy militarne. Centralnym punktem rozważań i celem niniejszego artykułu jest ukazanie wewnętrznych i zewnętrznych przyczyn interwencji militarnej Federacji Rosyjskiej na wschodzie Ukrainy.

Słowa kluczowe: obszar postradziecki; Federacja Rosyjska; Ukraina; polityka zagraniczna; konflikty zbrojne; geopolityka 


\section{Introduction}

The political activity of states constantly changes in response to the dynamic nature of the surrounding environment. The collapse of the USSR led to geopolitical changes on the Eurasian continent and the collapse of the bipolar balance of power in international relations. The newly established states in the post-Soviet sphere, and especially the Russian Federation, had to redefine their identity, role and position in the international arena. When analyzing this issue, reference should be made to qualitative research, which, while not being easy to formulate, is necessary when examining the complexity of factors impacting a state's strategy in the international environment. It should be noted that for the Russian Federation, the size of its territory is of paramount importance and is the key criterion that determines its position in the world (Bryc, 2012, p. 23). For this reason, it is not surprising that the President of the Russian Federation, V. Putin, who, during his address on the state of affairs before the Federal Assembly in 2005, said that: "Above all, we should acknowledge that the collapse of the Soviet Union was a major geopolitical disaster of the century. As for the Russian nation, it became a genuine drama. Tens of millions of our co-citizens and compatriots found themselves outside Russian territory" (Annual Address..., 2005; Panov, 2010, p. 90).

For Russian society, the collapse of its great empire constituted a humiliation. Additionally, during his speech V. Putin stated that the collapse of the USSR meant: "Millions of people went to bed in one country and awoke in different ones, overnight becoming ethnic minorities in former Union republics, while the Russian nation became one of the biggest, if not the biggest ethnic group in the world to be divided by borders". He continued: "[Russia] humbly accepted the situation. This country was going through such hard times then that realistically it was incapable of protecting its interests" (Obrashcheniye Prezidenta Rossiyskoy Federatsii, 2014).

When analyzing the activities (military and non-military) that the Russian Federation engages in with regard to the post-Soviet states, one can identify them as a priority of the Russian Federation's foreign policy, and the maintenance of influence (political, military and economic) in this region is perceived as one of the key elements determining Russia's status in the international arena. The authorities of the Russian Federation are of the opinion that without exerting influence on its immediate environment, the state will not be able to guarantee its security and, as a consequence, to increase its strength. Due to its interest in the post-Soviet area, Russia reacts on multiple fronts to actions which are perceived as attempts to reduce its importance in the region, and the military option is often taken by Russian decision-makers to achieve their current goals (Romańczuk, 2015). 
An example of such a policy is the military action taken by the Russian Federation against Ukraine (the annexation of Crimea and the war in eastern Ukraine). It has resulted not only in a change in this region's security system but has also had an impact on international security through the involvement of (mainly diplomatic) actors of international politics. As D. Trenin points out, the impact of this conflict on international relations has brought about: "the end of a more general phase of cooperation in international relations and the beginning of a new period of increased rivalry and even confrontation between former Cold War opponents" (Trenin, 2014). The Russian Federation was seriously concerned by the expansion of the European security zone through the integration of Central European countries into the EU and NATO structures, and especially by the pro-European aspirations expressed in Georgia and Ukraine.

The thesis put forward in this article is the following: the Russian Federation initiates armed conflicts in the post-Soviet area (the 'policy of destabilization' - in the case of Ukraine this destabilization took the form of a hybrid war) in order to secure its political, military and economic interests, and, in a longer term, to benefit from the imposed conflict settlement model. In addition, Russia has the potential to create and manage conflicts in the post-Soviet area (a policy of escalation and de-escalation, as needed), which it uses to coerce the countries of the region to forsake plans of integration with the Euro-Atlantic structures. This policy makes it impossible to begin constructive talks which will end these conflicts. The activities of the Russian Federation are the result of both geopolitical conditions and the Russian concept of state development through territorial expansion (the Eurasian identity of the Russian Federation).

When analyzing the activities of the Russian Federation with regard to Ukraine, it is necessary to refer to the theories of rivalry in international relations. In order for there to be rivalry, there must be a conflict of interests which could (but does not have to) lead to violent conflicts. In the case of Ukraine and the Russian Federation, the government in Kiev feels threatened by the government in Moscow. Yet at the same time it is difficult to view Ukraine as a threat to Russia. In the case of Ukraine and the Russian Federation, the conflict of interests revolves around the former's sovereignty, namely Ukraine wants to be able to pursue independent, internally-decided polices and Russia wants to control this country, manage its political structures, and questions its right to the existence as independent entity.

In this context, it is necessary to address the rivalry through employing the criteria of planes or spheres. As A. Włodkowska-Bagan points out, rivalry can be divided according to the sphere in which it occurs: political (maintaining or changing the status quo; maintaining or expanding influence), military (maintaining or 
strengthening military presence, e.g., in a given region), economic (access to markets or natural resources), or cultural-ideological (broadening the sphere of influence of the state's values and ideas, political system, religion) (Włodkowska-Bagan, 2012). However, different types of rivalry should not be examined in isolation, as they may overlap or occur in parallel. In addition, competition for dominance in the region may entail international competition, as increasing the regional position may also have the effect of increasing the global position. An example here may be the regional activities of the Russian Federation in the post-Soviet area, which then have an impact on its international position.

The theoretical approach to researching rivalry in international relations to which A. Włodkowska-Bagan refers to is the approach of socialization, which has its roots in sociology. In terms of international relations, socialization may concern states (as either current or prospective members of the system). This type of situation arises in particular (but not only) when there are changes in the international order, as a result of which new states are often created. The most important members of the system are primarily those who build it, i.e., the great powers. They are the most important socializers, as it is they who create the system, its principles and norms. Since there are several great powers, they all want to play the role of socializer in order to gain influence over countries similar to themselves (expansion of influence), over other countries, and to spread their culture and values. This, in turn, can lead to rivalry between the powers (Włodkowska-Bagan, 2012).

A second concept employed by A. Włodkowska-Bagan is that of punctuated equilibrium, which is taken from the natural sciences and applied to research on rivalry. According to this author, stable and conflict-free relations between a dyad of states are disrupted by a specific event or events, known as political shocks. Following such shocks, the states enter into a relationship of rivalry, which often endures. A political shock (a violent change in the international system) can be a world war, the collapse of a superpower, the emergence of new states, a change in the political system, or a civil war.

\section{Post-Soviet Space in Russian Collective Imagination and Strategic Thinking}

After the collapse of the USSR, it was difficult for the Russian society to accept the separation of Ukrainian and Belarusian territories, which had been the key element of the power of the tsarist Russia, and later the USSR (Bieleń, 2006, p. 125). The idea of the unity of all the lands inhabited by the Eastern Slavs was shaped by 
the concept of the "Third Rome". This myth had previously been exploited by the Romanov dynasty, which was credited with the unification of all Russian lands and the defense of the Orthodox faith. It was also connected with the belief that the true Christianity existed in the Russian lands: the Orthodox faith in its uncontaminated form and a fair social system. This concept was born in Slavophile circles and became the official state ideology in the mid-19 ${ }^{\text {th }}$ century (Świder, 2016, pp. 35-58). The ideology of Holy Rus also played a significant role in the efforts to assimilate and incorporate Ukrainian and Belarusian lands into Russia, which are united by the common Russian language (Russians considered Belarusian and Ukrainian languages as simply two dialects of their own language) and shared Orthodox religion. Restoring the unity of the Slavs was the goal of the Russophiles, while reunification was to take place under the leadership of Russia, which was synonymous with Holy Rus (Osadczy, 2007, pp. 98-99).

The idea of "Holy Rus" derived from the belief in Russian messianism. It was later developed by Lev Gumilev, who defined Holy Rus as synonymous with the super-ethnos of Eurasian civilization ${ }^{1}$, in which the Orthodox Church plays primary role in the society, and its spiritual functions are second to the political ones. Kirill, current Patriarch of Moscow and all Rus often invokes (or refers to) the idea of "Holy Rus", being of the opinion that today it consists of Russia, Ukraine, and Belarus. He opposes the emergence of autocephalous Orthodox churches in these countries, because in his view Belarusians and Ukrainians should remain under the sovereignty of the Russian Orthodox Church (Olszański, 2018). During his visit to Ukraine on the occasion of the $1020^{\text {th }}$ anniversary of the baptism of Kievan Rus, Patriarch Kirill publicly stated that: "Russia, Ukraine and Belarus are Holy Rus. Holy Rus is the ideal of love, goodness and truth. Holy Rus is beauty, Holy Rus is strength and we, together with you, are one Holy Rus" (Matreńczyk, 2008, pp. 32-33).

${ }^{1}$ Lev Gumilev formulated the thesis that Russia in Eurasia should be perceived as an autonomous and self-sufficient cultural type. It was to be based on ethnogenesis, which combined natural and geographical conditions with the political system of the state. However, each ethnos is formulated in different physical and geographical conditions and microclimate. The beginning of a new ethnos comes from the vicinity of several ethne and at their junction there is a cultural mutation, while the development of a given ethnos is determined by its adaptation to geographical conditions. The multiplicity of ethne enables historical rhythms in Eurasia and makes it unique. However, superethnos as a system of many ethne is not a spiritual or political community, but a natural one. Thus, the Eurasianists explained the possibility of the creation of the USSR as a superethnos. See more: Shnirelman \& Panarin (2001). 
The majority of Belarusian and Ukrainian people are Orthodox, and in Russia their culture and language are treated as being close. Hence, the widely held belief in Russia that there is a common ethnogenesis and unity of the Great Russians (Russians and Little Russians), Ukrainians and Belarusians, and the territories inhabited by them are considered to be "indigenously Russian" (Wierzbicki, 2012, p. 97). At present, the belief in the civilizational, cultural and religious ${ }^{2}$ unity of the Eastern Slavs is very strong among the Russian intellectual and political elite, despite the existence of independent Belarus and Ukraine. For this exact reason, the Council of the Slavic Nations of Belarus, Russia and Ukraine was established in June 2001. Another example of the institutionalization of cooperation between these three nations is the establishment in 2007, by a decree of V. Putin, of the Russkiy Mir Foundation, which is financed from the state budget. This organization was to be created not only by ethnic Russians, but also by all people from the "near abroad"3 who identify with the language, culture and history of Russia. Its aim is also to promote the Russian language abroad and popularize Russian culture by organizing courses and financing scholarships (Makarychev \& Yatsyk, 2017, p. 29).

It is worth noting that Russian identity is not based on a clear ethnic component, which is unusual as such components are often integrated into identity building processes. The reason for this is the "imperial identity", which gave the Russians a very weak sense of "ethnic identity". Ethnicity is also ignored in Russian political discourse. For example, the Preamble of the Russian Constitution states that: "We, the multinational people of the Russian Federation, united by a common destiny on our land [...]" (The Constitution of the Russian Federation, 1993). This omission of clear ethnic ties can prevent antagonizing the peoples and different ethnic groups living in Russia, of which there are more than one hundred. President V. Putin has also added aspects of "imperial and Soviet traditions" to consolidate national identity, for building the image and international position of the state.

After the collapse of the USSR in 1991, it was necessary for the Russian Federation to define its identity in the international arena. One of the most important factors underpinning the ideology of modern Russia is the tradition of being a su-

2 The Ukrainian Greek Catholic Church, which in some areas of Western Ukraine claims the majority of believers, cannot be treated as a national religion. The number of adherents in other parts of Ukraine, Belarus and Russia is negligible.

3 The term is used to describe countries that were once part of the USSR, and are now considered to belong to the Russian sphere of influence. 
perpower and empire. The Russian Federation, by invoking the imperial past of the USSR, attempted to create a contemporary model of identification appropriate for a superpower with global aspirations. Today, Russia is creating an identity, including the international one, which is first and foremost built on references to the glorious history and past achievements, and not on present capabilities (Potulski, 2005, p. 5). In the Russian Federation, the empires of tsarist Russia and the USSR are being mythologized and assigned positive traits, and many Russians feel they are the heirs of this great imperial tradition. Nostalgia for the empire has led to the open expression in political and scientific circles of the view that the only right way for modern Russia to develop is along imperial lines. The international identity of the Russian Federation was shaped as an imperial identity, together with a specifically understood territorial space. These factors - imperialism and territorial space - interact and are interlinked because Russian viewed its power through the prism of territory (Ignatowicz, 2011, pp. 37-50).

There are two types of objective in foreign policy: basic and specific. The basic objectives include: guaranteeing state security, increasing the state's power, strengthening its international position and prestige (Sułek, 2003). For the Russian Federation the post-Soviet area is a priority, in all political, social and economic aspects. After the collapse of the USSR, this area was referred to as the "near abroad" and as a "buffer zone" that served to protect Russia from external attacks. The absolute objective of the Russian Federation's foreign policy is to consolidate the post-Soviet area, to strengthen loosened contacts with the states there and to safeguard its interests by preventing third countries from gaining influence in the region (Zięba, 2004, pp. 37-56). Russia seeks to eliminate any attempts made by other countries to act in this area and treats their activities as being part of a zerosum game. Researchers describe the importance assigned to this region as symptomatic of a post-imperial syndrome. It is also worth noting that, unlike the British and French colonies, the Russian "colonies" were located in the immediate vicinity of the Russian state (Marten, 2015, pp. 190-191).

\section{The Annexation of Crimea and War in Eastern Ukraine in Terms of Domestic Purposes}

The size and strength of Russian army plays a key role in the country's security policy. This is the result of geographical location, since Russia has long land borders and unstable neighbors. These factors contribute to the "besieged fortress" syndrome and the sense of being under constant threat and the need to assert its pow- 
er. In the Russian Federation, the army performs not only defensive functions but is also tasked with cementing the bonds between society and the authorities. That is why victories, such as the "Great Patriotic War", are so loudly celebrated in Russia. In addition, the use of Russian armed forces during conflicts determines the strategic directions of the Russian Federation's internal policy, serving, for example, to divert attention away from crises (political, economic and social). The Russian authorities, burdened with the responsibility for a bad political, economic or social situation, look for an "external enemy", thanks to which they can consolidate the society around them. Nationalist sentiments and superpower yearnings become popular when perception of looming threat is widespread (Laruelle, 2016, p. 55).

It is necessary to reiterate that the Russian Federation carried out a deliberate and planned operation in Ukraine, which was aimed at the annexation of Crimea and military intervention in Donbass. This operation was supposed to destabilize Ukraine's internal situation and change the security environment in Central and Eastern Europe. The actions of the Russian Federation after the flight of President Viktor Yanukovych - caused by Euromaidan, the largest ever pro-Western social protests in Kiev's Independence Square - were inevitable, because the Russian authorities perceived the states created after the collapse of the USSR as being within its exclusive sphere of influence, and subject to its national interest. On the other hand, the activities of Ukrainian society during Euromaidan were perceived as a threat to Russia's influence, because the Russian authorities had striven to maintain privileged political, military and economic relations with Ukraine. For Russia, its dominant position in Ukraine was supposed to ensure the security of its Western borders, as well as to strengthen its position in the international arena. In addition, the military action taken by the authorities in the Kremlin was aimed at marginalizing Ukraine in the international arena and limiting the influence of other states. This state of affairs was also influenced by Russia's disappointment with the Western countries and a conviction, held especially in Russian military circles, that Russia's security interests were threatened by NATO's expansion into Eastern Europe (Davies, 2016, p. 721).

For the Russian authorities, and especially for President V. Putin, who is the central figure of the authoritarian political regime in Russia, the annexation of Crimea was undoubtedly a great military and propaganda success in domestic politics. In this system, which was created by the Russian President himself, V. Putin has unlimited formal and informal power and is the main decision-maker and arbitrator in Russia, which is increasingly centralized politically. A specific feature of the Russian political system is that statements of leaders determine the actions of state institutions, irrespectively of the division of powers and constitutionally- 
binding decision-making processes (Menkiszak, 2015, p. 84). When justifying the reintegration of Crimea with Russia, V. Putin invoked historical memory and the superpower status of Russia, and used his rhetoric to target the more emotional and nationalistic moods of Russian society. The politics of mythologization is a political strategy used by Russian political decision-makers. It is widely used in the Russian media, in which the annexation of Crimea was presented as the reconstruction of a great empire and the consolidation of Russian lands, and these actions were to restore the former prestige and position of the superpower (Clay, 2016).

After the Russian military invasion of Ukraine, V. Putin was hailed in the media as a defender of the Russian nation. Thanks to this, his popularity ratings increased significantly, as did people's trust in him, reaching a record level of $89 \%$ in support in June 2015, despite economic difficulties (e.g., the dramatic drop in ruble's value) (Nardelli, Rankin, \& Arnett, 2015). At the same time, according to a study by the Levada-Center from August 2016, 52\% of Russians respond positively to the slogan "Russia for Russians" (Levada-Center, 2016). The intensification of nationalist attitudes is subject to fluctuations which depend on how it is used in state propaganda. The increase in support for V. Putin should be explained - as was mentioned earlier - by the fact that $41 \%$ of Russians, as well as V. Putin himself, consider the collapse of the USSR as a "great geopolitical disaster" for Russia and that the Russian-speaking population abroad should be "protected" by all possible means (Levada-Center, 2017).

The annexation of Crimea and the Russian Federation's participation in the war in Eastern Ukraine enabled the mobilization of society in a military-patriotic direction, depicting Russia as a "besieged fortress". The aim was to integrate society around the Kremlin and protect its current political regime (Jędrzejewski, 2015, pp. 167-168). It became a successful propaganda tool for the authorities, who wanted to show the increasing power of the Russian Federation in the world and restore Russian society's sense of national pride. The Minister of Foreign Affairs of the Russian Federation, S. Lavrov, clearly emphasized this, stating that the priority in the foreign policy of the Russian Federation would be to support the Russians living outside the country's borders, by all possible means. There is also a visible degree of mobilization and militarization of society around military affairs and the image of V. Putin as the leader of the nation (Motyl, 2016, p. 33). Additionally, for domestic consumption, the Russian media created the image of the President of the Russian Federation as a defender of the Russian nation and of its national interests against the actions of Western countries, especially the USA and NATO, which are said to be focused on weakening the power and influence of the Russian Federation in the international arena (Sperling, 2016, p. 17). The Russian media blamed 
the United States and the European Union for intensifying antagonism and international rivalry with the Russian Federation. It is also pointed out that the introduction of economic sanctions was aimed at weakening Russia's potential for global competition. The Russian media also emphasized that Western countries were the first to pursue an aggressive policy with regard to the Russian Federation, and that President V. Putin was thus forced to defend national interests, including the use of military force. In addition, the myth of the "besieged fortress" implies the need for a strong leader - in the guise of V. Putin - to be the defender of the Russian nation.

According to surveys conducted by the Levada-Center in December 2014, 48\% of respondents stated that demonstrations in Ukraine and the following political changes in this country were "an attempt to organize another color revolution", while 56\% said that it was the Western states that were "trying to drag Ukraine into the orbit of [Western] interests" (Sperling, 2016, p. 18). In addition, when asked by the Levada-Center in July 2015 whether "the USA is using Russia's difficulties to transform the country into a second-rate state and a supplier of raw materials to the West", $86 \%$ of the respondents agreed with the statement, while only $7 \%$ opposed it (Levada-Center, 2015a). Moreover, in November 2015, only 21\% of respondents were concerned about the negative reactions of the West due to the role of Russia in Crimea and Donbass, and $71 \%$ said that they were not worried at all (LevadaCenter, 2015b). It is evident from these studies that Russian society believes in the political narrative presented by its ruling elites. President V. Putin has repeatedly questioned, more or less openly, the territorial integrity of the Ukrainian state and even its very right to existence. An example of this is the 2008 NATO summit in Bucharest, during which he told G.W. Bush, the then US president, that Ukraine is not a real country and, in his opinion, is an artificial creation: "[...] Generally speaking, Ukraine is a very complicated state. Ukraine, in the form it currently exists, was created in the Soviet times, it received its territories from Poland - after the Second World War, from Czechoslovakia, from Romania - and at present not all the problems have been solved as yet in the border region with Romania in the Black Sea". And earlier he stated: "[...] in Ukraine, one third are ethnic Russians. Out of forty five million people, in line with the official census, seventeen millions are Russians" (Text of Putin's Speech..., 2008). In addition, at the annual meeting of the "Valdai" Discussion Club on October 24, 2014, in which international and national experts participated, the Russian president stated that Ukraine is made up of pieces from other countries (Menkiszak, 2015, p. 93). Furthermore, V. Putin has repeatedly and publicly stated that Russia has a historical right to the eastern and southern regions of Ukraine, which were wrongly added to Ukraine because most of the inhabitants of these regions are Russians (Kuzio, 2016, p. 3). After the an- 
nexation of Crimea, during his speech at the Russian Parliament V. Putin declared that Ukraine had been in a state of continuous political crisis for over 20 years (Menkiszak, 2015, p. 92) and "[...] that what was called Novorossiya (New Russia) back in the tsarist days - Kharkov, Lugansk, Donetsk, Kherson, Nikolayev and Odessa - were not part of Ukraine back then. These territories were given to Ukraine in the 1920s by the Soviet government. Why? Who knows. They were won by Potyomkin and Catherine the Great in a series of well-known wars. The center of that territory was Novorossiysk, so the region is called Novorossiya. Russia lost these territories for various reasons, but the people remained. [...]" (Direct Line with Vladimir Putin, 2014).

For domestic consumption V. Putin articulates the message that pro-Russian separatists not only fight against the regular army of Ukraine but also against troops sponsored and trained by the United States and NATO. On the other hand, he asserts that Russian activities in Eastern Ukraine and the annexation of Crimea only serve to protect Russian national interests and limit the influence of Western states which aim to deprive Russia of its status as a key player in the international arena. Undoubtedly, this is an element of information warfare, which is of critical importance in the era of hybrid wars (Khapaeva, 2016, p. 65).

\section{Conclusion}

For the Russian Federation, Ukraine, especially its south-eastern part, and the Crimean Peninsula occupy a central place in the creation of its imperial identity, which dates back to the eighteenth-century Russian Empire under Catherine the Great. V. Putin uses the historical name of Novorossiya when referring to this area, and has repeatedly expressed his belief in the historical injustice of the transfer of the Donbass in 1922, and the Crimean Peninsula with Sevastopol in 1956, to the Ukrainian SSR (Freedman, 2014, p. 13). Such thinking definitely rules out the possibility of an agreement being signed on the end of the conflict in Eastern Ukraine, let alone the return of the Crimean peninsula by the Russian Federation, despite the economic sanctions imposed on Russia by the West. Additionally, V. Putin stated during the annual meeting of the international "Valdai" Discussion Club in October 2014 that "[...] Russia is not going to get all worked up, get offended or come begging at anyone's door. Russia is a self-sufficient country. We will work within the foreign economic environment that has taken shape, develop domestic production and technology and act more decisively to carry out transformation. Pressure from outside, as has been the case on past occasions, will only 
consolidate our society, keep us alert and make us concentrate on our main development goals. Pressure from outside, as has been the case on past occasions, will only consolidate our society [...]" (Meeting of the Valdai..., 2014).

Researchers belonging to the realist trend blame Ukraine itself and Western countries, especially the USA, for the events that unfolded in Ukraine. In their view, Ukraine should become a buffer state, like Finland, between Russia and Western states, while Ukraine's potential membership in the EU and NATO is only a provocation to the authorities in the Kremlin. This is due to the fact that Ukraine is treated only as an object in the rivalry between the stronger players of international politics (Kuzio, 2016, pp. 8-9). However, the question arises as to whether neutrality along the lines of Finland or Austria during the "Cold War" had been really an option. It seems that neutrality under the auspices of the Russian Federation would be more like "vassalization", similar to the relationship that Belarus under Alexander Lukashenko has with Russia. However, one positive outcome of the conflict in Ukraine is that it has resulted in a sense of national unity forming in Ukrainian society.

It has to be said that viewing Russian actions, i.e., the annexation of Crimea and the war in Eastern Ukraine, solely as a punishment of Ukraine for not following the rules of the "game" is a mistake. These actions were driven by the ideological goals of "rebuilding" the Russian Empire and restoring national pride for the sake of domestic politics. In addition, Russian President V. Putin justified these actions with geopolitical arguments, stressing Russia's moral duty to protect the Russianspeaking population living outside the Russian borders and their alleged willingness to rejoin their motherland (Laruelle, 2015, p. 88). These arguments may be a threat to neighboring states with large Russian-speaking minorities, such as Estonia, Latvia and Kazakhstan. Russian authorities, under the pretext of defending the ethnic Russians, may try to destabilize the internal situation in these countries.

In the medium term, it should be noted that there are two possible courses of action that the authorities of the Russian Federation could follow with regard to Ukraine. The first scenario is that the Russian government will not be interested in putting the conflict to an end, and thus in embarking on compromise solutions with Ukraine. This will then be another "frozen conflict" in the post-Soviet area, along the lines of Transnistria, Abkhazia and South Ossetia. It will be used by the Kremlin authorities as a tool for the political and social destabilization of Ukraine. The second scenario is that the Russian Federation will agree to leave the Donbass within the borders of the Ukrainian state as long as the government in Kiev agrees to federalize the country and transfer more powers to the regions. Donbass, on the other hand, would gain broad autonomy with guaranteed Russian influence. 
Thus decentralized, Ukraine would not be able to effectively manage its own state. Thanks to its influence in the eastern parts of the country, Russia could thereby exert influence over other parts of Ukraine.

Russia's objective in the post-Soviet area continues to be to regain political and economic control over the whole of Ukraine, while the minimal plan is to control part of Ukrainian territory and to prevent integration into Euro-Atlantic structures. In all likelihood, the sanctions policy will not bring the intended results because V. Putin simply will not yield to the actions of Western states. Russia can maintain such an adamant attitude towards the West partly thanks to the development of relations with partners from the Far East, among others from the PRC. It should also be noted that the macroeconomic difficulties associated with sanctions, and thus the possible social unrest in Russian society, may lead to an escalation of the Donbass conflict, deliberately managed by the authorities, in order to divert the attention of the Russian population from internal problems. On the other hand, the aim of foreign policy is to force Western countries, and especially the United States of America - through accompanying ideological confrontation - to participate in talks on the creation of a new system of international security (in the understanding of the Russian authorities this entails building a multipolar world and creating so-called spheres of influence). Peace talks concerning Ukraine may be one of the elements of such negotiations.

\section{References:}

Annual Address to the Federal Assembly of the Russian Federation (2005, April 25). Retrieved from: http://en.kremlin.ru/events/president/transcripts/22931.

Bieleń, S. (2006). Tożsamość międzynarodowa Federacji Rosyjskiej. Warszawa: Oficyna Wydawnicza ASPRA-JR.

Bryc, A. (2012). Wpływ geopolityki na tożsamość międzynarodową Polski i Rosji. In: S. Bieleń, \& A. Skrzypek (Eds.). Geopolityka w stosunkach polsko-rosyjskich (pp. 23-43). Warszawa: Oficyna Wydawnicza ASPRA-JR.

Clay, A. (2016). Assessing Russia's Ban on U.S. Adoptions from a Constructivist Framework of Image Construction. Pursuit: The Journal of Undergraduate Research at the University of Tennessee, 7(1), Article 7, 33-42.

Davies, L. (2016). Russia's 'Governance' Approach: Intervention and the Conflict in the Donbas. Europe-Asia Studies, 68(4), 726-749. DOI: 10.1080/09668136.2016.1173652.

Direct Line with Vladimir Putin (2014, April 17). Retrieved from: http://eng.kremlin.ru/ news/7034.

Freedman, L. (2014). Ukraine and the Art of Limited War. Survival. Global Politics and Strategy, 56(6), 7-38. DOI: 10.1080/00396338.2014.985432. 
Ignatowicz, K. (2011). Dziedzictwo historyczne jako wyznacznik postrzegania współczesnej Rosji. In: S. Bieleń (Ed.). Wizerunki międzynarodowe Rosji (pp. 37-72). Warszawa: Oficyna Wydawnicza ASPRA-JR.

Jędrzejewski, W. (2015). Surowce energetyczne a przyczyny wojen: casus konfliktu na Ukrainie. In: O. Kwiatkiewicz, \& R. Szczerbowski et al. (Eds.). Bezpieczeństwo energetyczne: Rynki surowców i energii. Energetyka w czasach politycznej niestabilności. Bezpieczeństwo, gospodarka, ochrona środowiska, polityka, technologia, zarzadzanie (pp. 163-176). Poznań: Wydawnictwo FNCE.

Khapaeva, D. (2016). Triumphant Memory of the Perpetrators: Putin's Politics of ReStalinization. Communist and Post-Communist Studies, 49(1), 61-73. DOI: 10.1016/j. postcomstud.2015.12.007.

Kuzio, T. (2016). Nationalism and Authoritarianism in Russia: Introduction to the Special Issue. Communist and Post-Communist Studies, 49(1), 1-11. DOI: 10.1016/j.postcomstud.2015.12.002.

Laruelle, M. (2015). Russia as a "Divided Nation," from Compatriots to Crimea: A Contribution to the Discussion on Nationalism and Foreign Policy. Problems of Post-Communism, 62(2), 88-97. DOI: 10.1080/10758216.2015.1010902.

Laruelle, M. (2016). The Three Colors of Novorossiya, or the Russian Nationalist Mythmaking of the Ukrainian Crisis. Post-Soviet Affairs, 32(1), 55-74. DOI: 10.1080/1060586X.2015.1023004.

Levada-Center (2015a). Rossiya - Zapad: vospriyatiye drug druga v predstavleniyakh rossiyan. Retrieved from: http://www.levada.ru/2015/06/26/rossiya-zapad-vospriyatiedrug-druga-v-predstavleniyah-rossiyan/.

Levada-Center (2015b). Rossiysko-ukrainskiye otnosheniya, "Krymnash". Retrieved from: http://www.levada.ru/2015/11/23/rossijsko-ukrainskie-otnosheniya-krymnash/.

Levada-Center (2016). Intolerantnost' $i$ ksenofobiya. Retrieved from: http://www.levada. $\mathrm{ru} / 2016 / 10 / 11 /$ intolerantnost-i-ksenofobiya/.

Levada-Center (2017). Nostalgia for the USSR. Retrieved from: https://www.levada.ru/ en/2017/12/25/nostalgia-for-the-ussr/.

Makarychev, A., \& Yatsyk, A. (2017). Biopower and Geopolitics as Russia’s Neighborhood Strategies: Reconnecting People or Reaggregating Lands? Nationalities Papers: The Journal of Nationalism and Ethnicity, 45(1), 25-40. DOI: 10.1080/00905992.2016.1248385.

Marten, K. (2015). Putin's Choices: Explaining Russian Foreign Policy and Intervention in Ukraine. The Washington Quarterly, 38(2), 189-204. DOI: 10.1080/0163660X.2015.1064717.

Matreńczyk, A. (2008). Jednoczy nas matka ruskich miast. Przeglad Prawostawny, 8. Retrieved from: http://archiwum.przegladprawoslawny.pl/articles.php?id_n=1832\&id=8.

Meeting of the Valdai International Discussion Club (2014, October 24). Retrieved from: http://en.kremlin.ru/events/president/news/46860.

Menkiszak, M. (2015). Borders in Flux: Ukraine as a Case Study of Russia's Approach to Its Borders. Eurasia Border Review, 6(1), 83-102. DOI: 10.14943/ebr.6.1.83.

Motyl, A.J. (2016). Putin's Russia as a Fascist Political System. Communist and Post-Communist Studies, 49(1), 25-36. DOI: 10.1016/j.postcomstud.2016.01.002. 
Nardelli, A., Rankin, J., \& Arnett, G. (2015, July 23). Vladimir Putin's Approval Rating at Record Levels. The Guardian. Retrieved from: https://www.theguardian.com/ world/datablog/2015/jul/23/vladimir-putins-approval-rating-at-record-levels.

Obrashcheniye Prezidenta Rossiyskoy Federatsii (2014, March 18). Retrieved from: http:// kremlin.ru/events/president/news/20603.

Olszański, T.A. (2018, June 11). “An Independent State Needs an Independent Church”: The Fight for Canonical Independence for Ukrainian Orthodoxy. Commentary OSW, 272. Retrieved from: https://www.osw.waw.pl/sites/default/files/commentary_272.pdf.

Osadczy, W. (2007). Święta Ruś. Rozwój i oddziatywanie idei prawostawia w Galicji. Lublin: Wydawnictwo UMCS.

Panov, P. (2010). Nation-building in post-Soviet Russia: What kind of nationalism is produced by the Kremlin? Journal of Eurasian Studies, 1(2), 85-94. DOI: 10.1016/j. euras.2010.04.001.

Potulski, J. (2005). Rola i znaczenie tradycji w funkcjonowaniu wspótczesnych instytucji politycznych $w$ Rosji. Toruń: Wydawnictwo Adam Marszałek.

Romańczuk, M. (2015). Implikacje doktryny militarnej Federacji Rosyjskiej na obszarze postradzieckim. Szczecin: Wydawnictwo Naukowe Wydziału Humanistycznego US „Minerwa”.

Shnirelman, V., \& Panarin, S. (2001). Lev Gumilev: His Pretensions as Founder of Ethnology and His Eurasian Theories. Inner Asia, 3(1), 1-18. DOI: $10.1163 / 146481701793647732$.

Sperling, V. (2016). Putin's Macho Personality Cult. Communist and Post-Communist Studies, 49(1), 13-23. DOI: 10.1016/j.postcomstud.2015.12.001.

Sułek, M. (2003). Modelowanie i pomiar potęgi państw w stosunkach międzynarodowych. Stosunki Międzynarodowe, 3-4, 69-99.

Świder, K. (2016). Geopolityka jako światopogląd władzy w Rosji. Teka Komisji Politologii i Stosunków Międzynarodowych - OL PAN, 11(3), 35-58. DOI: 10.17951/ teka.2016.11.3.35.

Text of Putin's Speech at NATO Summit (Bucharest, April 2, 2008) (2008, April 18). Retrieved from: https://www.unian.info/world/111033-text-of-putin-s-speech-at-natosummit-bucharest-april-2-2008.html.

The Constitution of the Russian Federation (1993). Retrieved January 21, 2021 from: http:// www.constitution.ru/en/10003000-01.htm.

Trenin, D. (2014, October 15). Ukrainskiy krizis i vozobnovleniye velikoderzhavnogo sopernichestva. Retrieved from: https://carnegie.ru/2014/10/15/ru-pub-56935.

Wierzbicki, A. (2012). Nacjonalizm i geopolityka w Europie Wschodniej. In: S. Bieleń, \& A. Skrzypek (Eds.). Geopolityka w stosunkach polsko-rosyjskich (pp. 87-121). Warszawa: Oficyna Wydawnicza ASPRA-JR.

Włodkowska-Bagan, A. (2012). Badania nad rywalizacją w nauce o stosunkach międzynarodowych. Stosunki Międzynarodowe, 45(1), 103-115.

Zięba, R. (2004). Cele polityki zagranicznej państwa. In: R. Zięba (Ed.). Wstęp do teorii polityki zagranicznej państwa (pp. 37-58). Toruń: Wydawnictwo Adam Marszałek. 